\title{
Competitive Potential of the Republic of Tatarstan on the Background of Regions of Canada
}

\author{
Saubanov K.R. ${ }^{\mathrm{a}}$ \\ Gafurov I.R. ${ }^{b}$ \\ Pratchenko O.V.c
}

aKazan Federal University, Institute of Management, Economics and Finance, Kazan, 420008, Russia

${ }^{b}$ Kazan Federal University, Institute of Language, 420008, Kazan, Russia

\section{Doi:10.5901/mjss.2014.v5n28p32}

\section{Abstract}

The article presents the results of comparative assessment of the competitive potential of the Republic of Tatarstan and the regions of Canada. There is a significant lag in productivity. in the Republic of Tatarstan. However, by a number of indicators the Republic of Tatarstan is ahead of some provinces of Canada. In the region there is some scope for productivity growth, which, in our opinion, is a basic indicator of the competitive potential of the territories. It is obvious that the task of achieving advanced growth of operational performance should be the key priority of regional economic policy not only in Tatarstan, but also in every Federal entity.

Keywords: productivity, Republic of Tatarstan, the province and Canada, competitive potential, assessment of competitive potential.

\section{Introduction}

This study is the first work in the frames of our new series of studies devoted to the comparative assessment of the competitive potential of the Republic of Tatarstan (RT) - one of the most developed regions of the Russian Federation with the regions of other countries.

In this case, the provinces of Canada chosen as the basis for comparison. It is connected with the fact that the Canadian economy, as well as Russian, has rich natural resource base, the presence of which allowed the country to establish deep cooperation ties with Western Europe and, above all, with the United States. This became one of the main factors that contribute to the affiliation of the state into the group of developed countries. However, the difference of the Canadian economy from the Russian one is that in Canada natural resources have become the real engine of economic growth and the driving force of competitive development. Today, the share of extractive industries in the Canadian economy is only about $8 \%$ of GDP (70\% of GDP falls on the service sphere!).

\section{Method}

The following indicators were used to assess the competitive potential of the Republic of Tatarstan in comparison with the regions of Canada: operational performance, output-wages, the share of capital investments in the GRP and the coefficient of advance of increase of labor efficiency of the average wages.

We offer to assess the competitiveness on the basis of the approach proposed in the work of E.A. Nikolaeva and others [1], which is based on determination of ranks using the method of standard coefficients. This method allows us to turn the original data to a single scale and eliminates the effect of different units of measurement on the final result.

The aim of the method of standard coefficients is to bring the indicators measured in different units (kilograms, percent, etc.), to the value from 0 to 1 (where 0 corresponds to the worst result, and 1, respectively, - to the best). If the major indicator corresponds to the best result (i.e., the regions have to increase the value of the index), the following formula is used:

$$
\bar{X}=\frac{X_{i j}-X_{\min i}}{X_{\max i}-X_{\min i}}
$$

where ${ }^{X_{i j}}$ - I indicator of $\mathrm{j}$ region, $X_{\min i}$ - the minimum value of the I indicator among the regions under study, $X_{\max }$ the maximum value of the i indicator among the regions under study.

If the minor indicator corresponds to the best result, the following formula is used: 


$$
\bar{X}=1-\frac{X_{i j}-X_{\min i}}{X_{\max i}-X_{\min i}}
$$

\section{Result}

The table 1 shows the distribution of GRP by regions and provinces of Canada in 2010-2012.

Table 1: Output of Gross Regional Product in the regions of Canada and the Republic of Tatarstan in 2010-2012, mln. USD, in current prices

\begin{tabular}{|c|l|c|c|c|c|}
\hline № & Region (province) & 2010 & 2011 & 2012 & 2010-2012, in average \\
\hline 1 & Ontario & 629500 & 654715 & 674485 & 652900 \\
\hline 2 & Quebec & 329670 & 345287 & 357859 & 344272 \\
\hline 3 & Alberta & 270100 & 298049 & 311898 & 293349 \\
\hline 4 & British Columbia & 205996 & 215148 & 219994 & 213713 \\
\hline 5 & Saskatchewan & 63379 & 73436 & 77929 & 71581 \\
\hline 6 & Manitoba & 52896 & 55169 & 58245 & 55437 \\
\hline 7 & Republic of Tatarstan (Russia) ${ }^{*}$ & 32862 & 39613 & 47314 & 39930 \\
\hline 8 & New Scotland & 37073 & 38147 & 38397 & 37872 \\
\hline 9 & Newfoundland and Labrador & 29063 & 33501 & 33817 & 32127 \\
\hline 10 & New Brunswick & 30082 & 31291 & 31543 & 30972 \\
\hline 11 & Prince Edward Island & 5202 & 5384 & 5547 & 5378 \\
\hline 12 & North-West Territories & 4787 & 4718 & 4675 & 4727 \\
\hline 13 & Yukon & 2313 & 2376 & 2631 & 2440 \\
\hline 14 & Nunavut & 1936 & 2036 & 2198 & 2057 \\
\hline
\end{tabular}

* - For the Republic of Tatarstan GRP is calculated on the basis of the official exchange rate of the US dollar for the year set by the Central Bank of the Russian Federation

Source: State Statistics Service of Canada http://www.statcan.gc.ca/

Thus, as we can see from Table 1, the size of the economy of the Republic of Tatarstan is comparable with such regions of Canada as New Scotland, Newfoundland and Labrador, New Brunswick. However, this comparison is very conditional, because of differences in the level of inflation (in Canada - about 2\%), the national currency rate, etc. between the RT and these areas.

In Table 2 the data on operational performance in the regions of Canada and the Republic of Tatarstan in 20102012 are given.

Table 2: Operational performance in the regions of Canada and the Republic of Tatarstan in 2010-2012, thousand USD of GRP per 1 employee

\begin{tabular}{|c|l|c|c|c|c|}
\hline № & Region (province) & 2010 & 2011 & 2012 & 2010-2012, in average \\
\hline 1 & Nunavut & 179,0 & 181,2 & 194,8 & 185,0 \\
\hline 2 & North-West Territories & 176,0 & 170,2 & 167,2 & 171,0 \\
\hline 3 & Alberta & 156,6 & 166,2 & 164,9 & 163,0 \\
\hline 4 & Newfoundland and Labrador & 149,3 & 168,0 & 163,9 & 160,0 \\
\hline 5 & Saskatchewan & 145,8 & 164,8 & 168,8 & 160,0 \\
\hline 6 & Yukon & 119,4 & 119,0 & 126,4 & 122,0 \\
\hline 7 & Ontario & 113,7 & 116,7 & 118,4 & 116,0 \\
\hline 8 & British Columbia & 111,4 & 114,4 & 115,5 & 114,0 \\
\hline 9 & Quebec & 99,0 & 102,6 & 105,2 & 102,0 \\
\hline 10 & New Brunswick & 95,5 & 100,2 & 102,4 & 99,0 \\
\hline 11 & Manitoba & 96,1 & 99,1 & 102,8 & 99,0 \\
\hline 12 & New Scotland & 92,2 & 95,0 & 96,6 & 95,0 \\
\hline 13 & Prince Edward Island & 82,1 & 84,6 & 87,9 & 85,0 \\
\hline 14 & Republic of Tatarstan (Russia) * & $\mathbf{1 8 , 2}$ & $\mathbf{2 1 , 8}$ & $\mathbf{2 5 , 9}$ & $\mathbf{2 2 , 0}$ \\
\hline
\end{tabular}

* - For the Republic of Tatarstan GRP is calculated on the basis of the official exchange rate of the US dollar for the year set by the Central Bank of the Russian Federation

Source: State Statistics Service of Canada http://www.statcan.gc.cal 
As we can see from the table above, in terms of operational performance the Republic of Tatarstan (25,9 thousand USD 2012) is greatly behind the regions of Canada, especially from Nunavut (194,8 thousand USD) and the Northwest Territories (167,2 thousand USD). However, these provinces are subsidized, and this fact introduces some distortion. At the same time, if we compare the Republic of Tatarstan with the quite self-sustainable Quebec, the gap in operational performance is also great -4 times.

The output-wages indicator which characterizes the ratio of the gross regional product and payroll in the region, is an important characteristic of the competitive potential of the territory. This indicator shows the quantity of units of gross domestic product are per unit of payroll. And essentially it shows how effective the payroll costs for salary are.

It is necessary to say that the average monthly salary in the Republic of Tatarstan is significantly lower than in any of the provinces of Canada. For example, in 2012 the salary in the Republic in terms of the foreign currency was only 765 US dollars. In Canada, the Northwest Territories lead by this indicator - 5156 USD for the same period. Even Prince Edward Island, where salary is the lowest among the provinces of the country (2966 dollars in 2012), gets significantly ahead of the Republic of Tatarstan by this indicator. In general, in 2012 the country's average monthly salary exceeded 3500 dollars (the expenses for meal in households are not less than $10 \%$ of all expenses!) However, this is nothing surprising. It is well known that the remuneration is directly proportional to the level of its performance.

Besides, it is necessary to emphasize that, according to the Statistical Service of Canada, in July 2014 the average monthly salary in the educational system of the country reached 4000 dollars. It is for $30 \%$ more than in the trade; it is identical to remuneration of labor in the sphere of in real estate; and it is only $17 \%$ less than in public administration and the financial sector.

Thus, once again our thesis that the competitiveness of the territory in the current socio-economic conditions is, first of all, the competitiveness of its educational and scientific system, is confirmed. Without modern and efficient scientific-educational sphere it is impossible to catalyze the formation of competitive areas. These are the principles of "knowledge economy".

Here there is a table in which the dynamics of the integral competitiveness index calculated for the regions of Canada and the Republic of Tatarstan is shown.

Table 3: Integral competitiveness index for the regions of Canada and the Republic of Tatarstan in 2010-2012

\begin{tabular}{|c|l|c|c|c|c|}
\hline № & Region (province) & 2010 & 2011 & 2012 & 2010-2012, in average \\
\hline 1 & Nunavut & 1,000 & 0,885 & 0,932 & 0,939 \\
\hline 2 & Saskatchewan & 0,590 & 0,801 & 0,728 & 0,706 \\
\hline 3 & Newfoundland and Labrador & 0,656 & 0,783 & 0,632 & 0,690 \\
\hline 4 & Alberta & 0,658 & 0,709 & 0,666 & 0,678 \\
\hline 5 & North-West Territories & 0,743 & 0,572 & 0,577 & 0,631 \\
\hline 6 & Yukon & 0,541 & 0,479 & 0,594 & 0,538 \\
\hline 7 & British Columbia & 0,398 & 0,429 & 0,423 & 0,417 \\
\hline 8 & Ontario & 0,365 & 0,422 & 0,425 & 0,404 \\
\hline 9 & Quebec & 0,321 & 0,377 & 0,392 & 0,363 \\
\hline 10 & Manitoba & 0,326 & 0,352 & 0,397 & 0,358 \\
\hline 11 & New Brunswick & 0,318 & 0,373 & 0,363 & 0,351 \\
\hline 12 & New Scotland & 0,286 & 0,351 & 0,322 & 0,320 \\
\hline 13 & Prince Edward Island & 0,242 & 0,300 & 0,311 & 0,284 \\
\hline 14 & Republic of Tatarstan (Russia) & 0,109 & 0,247 & 0,189 & 0,182 \\
\hline
\end{tabular}

Note: made by the authors on the basis of the index method by aggregating 4 indicators of competitiveness at the average value: $0,55 P T+0,15 Z P O+0,15 I N+0,15 K P T Z P$

As we can see from the table above, the competitive potential (within the given four-factor model) of the Republic of Tatarstan is significantly lower than of the regions of Canada. In this case, the integral index of Prince Edward Island in 2010-2012 was 56\% higher than $f$ Tatarstan.

\section{Conclusion}

The 4-factor model of competitive potential of the Republic of Tatarstan - in comparison with the regions of Canada showed that Tatarstan economy greatly lags behind from the Canadian provinces in terms of operational performance (by the number of areas - up to 8 times). 
However, among the positive sides it is necessary to say that in 2010-2012 the Republic of Tatarstan was ahead of some Canadian regions by such indicators as output-wages of GRP, share of capital investment in the regional product, ratio of the rates of growth of operational performance and salary. It means that in Tatarstan there are sufficient reserves to provide sustainable growth of operational performance. It is obvious that the task of achieving advanced growth of operational performance should be the key priority of regional economic policy not only in Tatarstan, but also in every Federal entity.

\section{References}

Nikolaeva E.A., Vanchikova E.N., Mescheryakov S.A. Formirovanie i otsenka konkurentosposobnosti munitsipalnyih obrazovaniy regiona. - Ulan-Ude: VSGTU, 2006.

Panasyuk M., Pudovik E., Malganova I., Butov G. Regional Multicultural Community: Problems of Life Quality Estimation // Mediterranean Journal of Social Science. - Vol.5. - №8. - pp. 323-327.

D. Kh. Gallyamova, A.R. Toumashev, V.V. Malaev. Influence of Globalization on Development of the Russian Economy I/ Mediterranean Journal of Social Science. - Vol.5. - №18. - pp. 133-138.

Egorov, E.,Razumovskaya, E.,Tarhanov, I., Kucevol, N.,Calikova, V. Methodological bases of system of social service of the population. Middle East Journal of Scientific Research vol. 18 (1), pp. 9-12

Razumovskaya, E.M. , Kutsevol, N., Popov, M., Mishakin, T., Leto, L., Tsalikova, V. The effectiveness of management practice in the market of socially important services. Asian Social Science, Volume 10, 28 September 2014, Pages 118-122

Razumovskaya, E.M.,Lapidus, L.V., Mishakin, T.S., Popov, M.L. Features and peculiarities of the Russian passenger rail market development. Mediterranean Journal of Social Sciences vol. 5 (18 SPEC. ISSUE), pp. 165-170.

Palei Tatyana, Salakhatdinova Leisian. The study of the phenomenon of creativity in education. Procedia - Social and Behavioral Sciences Vol. 131, pp. 90-96// 3rd World conference on educational technology researches. Turkey 07-09.11.2013.

Mingazova N.M. Modification of Active Learning in Environmental Education Russian Universities. Procedia - Social and Behavioral Sciences Vol. 131, pp. 85-89 // 3rd World conference on educational technology researches Turkey 07-09.11.2013. 